\title{
Correction: Unraveling the genetic complexity underlying sorghum response to water availability
}

Nguyen Phuong, Gloria Afolayan, Hartmut Stützel, Ralf Uptmoor, Mohamed El-Soda

The following information is missing from the Funding statement: This study was supported by Deutsche Forschungsgemeinschaft and Universität Rostock within the funding programme Open Access Publishing (to RU).

\section{Reference}

1. Phuong N, Afolayan G, Stützel H, Uptmoor R, El-Soda M (2019) Unraveling the genetic complexity underlying sorghum response to water availability. PLoS ONE 14(4): e0215515. https://doi.org/10. 1371/journal.pone.0215515 PMID: 30998785

\section{G openaccess}

Citation: Phuong N, Afolayan G, Stützel H, Uptmoor R, El-Soda M (2019) Correction: Unraveling the genetic complexity underlying sorghum response to water availability. PLOS ONE 14(9): e0222859. https://doi.org/10.1371/journal. pone.0222859

Published: September 17, 2019

Copyright: ๑ 2019 Phuong et al. This is an open access article distributed under the terms of the Creative Commons Attribution License, which permits unrestricted use, distribution, and reproduction in any medium, provided the original author and source are credited. 